\title{
Islamic Da'wah in Industrial Society: Study on Employees of PT Indorama Synthetics Tbk Purwakarta
}

\author{
Zaenal Mukarom \\ UIN SGD Bandung \\ zaenal.mukarom@uinsgd.ac.id
}

\begin{abstract}
This study aims to find out and reveal the religious behavior of PT Indorama Synthetics Tbke employees and the Da'wah activities of PT Indorama Synthetics Tbk. This study uses a naturalistic paradigm with a qualitative approach that uses case studies. Data collection techniques are obtained through observation and interviews. The results showed that the religious behavior of industrial societies still tends to be normative and formalistic; the Da'wah activities of industrial organizations are still temporal, monumental, and ceremonial. The development and implementation of Da'wah on industrial societies need to be conveyed with more contemporary and contextual themes, especially about the event of Da'wah Syu'ubiyah with the right and effective strategies.
\end{abstract}

Keywords: Industrial Society; Religious Behavior; Da'wah Activities.

\begin{abstract}
ABSTRAK
Studi ini bertujuan untuk mengetahui dan mengungkapkan tentang perilaku keberagamaan karyawan PT Indorama Syntehtics Tbk dan Aktifitas Dakwah Karyawan PT Indorama Synthetics Tbk. Studi ini menggunakan paradigma naturalistik dengan pendekatan kualitatif. Penelitian menggunakan studi kasus. Teknik pengumpulan data dilakukan dengan observasi dan wawancara. Hasil penelitian menunjukan bahwa, perilaku keberagamaan masyarakat industri masih cenderung normatif dan formalistis, aktifitas dakwah masyarakat industri masih bersifat temporal, monumental, dan seremonial. Pengembangan dan pelaksanaan dakwah di masyarakat industry perlu disampaikan dengan tema-tema yang lebih kontemporer dan kontekstual terutama berkenaan dengan pengembangan dakwah syu'ubiyah dengan strategi yang tepat sasaran dan tepat guna.
\end{abstract}

Kata kunci : Masyarakat Industri; Perilaku Keberagamaan; Aktifitas Dakwah. 


\section{BACKGROUND}

Purwakarta is industrializing regions in several sectors, such as clothing, food, tourism, and culture. Many factories are scattered in the Purwakarta region, making Purwakarta Regency an urbanized area undergoing industrialization and modernization. Some large factories that have been established and operated in Purwakarta, namely PT Bongman International Factory, PT Japfa Comfeed Indonesia, PT South Pacific Viscose Lenzing, PT Kinenta Indonesia, PT EastWest Indonesia, PT Indorama Synthetic Tbk, and others. Based on observation, there are more than 20 large factories established in Purwakarta. There was a special area where the factory was located, namely the Industrial Estate of Bukit Indah City (BIC) Purwakarta. The number of factories in the area made Purwakarta became an industrial area, including the community, which began to transform into an industrial society. In its development as an industrial area, it also became a magnet for migrants to find work as employees in several existing factories.

The transformation of Purwakarta into an industrial area, on the other hand, brought various changes from social, cultural, and religious aspects. From a social aspect, it is very clear that there has been a change in the social system from an agrarian society to an industrial society. Furthermore, the geographical conditions also naturally experienced a change. Namely, the disappearance of rice fields, plantations, and forests, turned into factory buildings. From the cultural aspect, there is a shift in the community's culture, which initially made a living by farmers and traders, switching professions that are dominated by factory employees. Another aspect, which is also affected is religion. The Purwakarta community is increasingly heterogeneous because many migrants work as factory employees, participate in bringing their culture and personal religious understanding with their various backgrounds.

PT Indorama Synthetics Tbk is one of the largest factories in Purwakarta. The factory, which operates in the clothing industry sector, has thousands of employees from various regions, not only from Purwakarta but many also come from outside the Purwakarta. PT Indorama Synthetics Tbk is a commercial company that has been established since 1976. PT Indorama Synthetics Tbk is a large textile company located in the industrial area of Purwakarta. The production activities of this textile factory cover three business fields, namely: yarn spinning, polyester filament production, and polyester staple fiber. Production results from the textile industry are traded nationally and internationally. For the import scale, the production of PT Indorama Synthetics Tbk Purwakarta is traded to Asian, European, American, African, and Middle Eastern regions. From the aspect of its human resources, of course, the textile industry company has many employees. Based on PT Indorama Synthetics Tbk's Financial Statements (March 2019), the number of employees reached 8,000. A 
large number of employees have further confirmed PT Indorama Synthetics Tbk as a national-scale industrial company in Purwakarta.

Industrial society orientates activities and fulfills its needs from the results of industrial and modern technology. A concrete example of industrial society can be found in developed countries like America, Germany, France, and England. Society, as a social group, from the perspective of sociology, can be classified into several categories: agrarian society, industrial society, and information society. Soerjono Soekanto (2007: 37) briefly explains the distinction of these three categories of society from the perspective of the resources they process, namely: (1) The agrarian society, the resources it processes are natural resources, such as land and water. ; (2) The industrial society whose processed industrial technology and product resources; (3) Information society whose processed information and communication resources. John Scott (2012: 327) also explained that for an agrarian society, the main resources needed are raw materials or nature, while for the industrial society, the resources needed are capital. For information society, the most primary resource is knowledge.

Based on these transformations, industrial society manifests as a society that has different characteristics. Based on the identification results, there are some essential characteristics in industrial society, namely: (1) The massive production of industrial goods by utilizing machine technology; (2) The occurrence of mass urbanization; (3) Many factories were built as the leading employment sector,; (4). Communities with secondary education begin to dominate; and (5) The existence of information and communication media specifically for the industrial community. The fundamental characteristic inherent in the industrial society is obtained from the results of identification and observation of the employees of PT Indorama Synthetics Tbk. They represent an industrial society in Purwakarta.

More specifically, industrial society also has unique psychological and sociological characteristics. M. Zakaria Al-Anshori (2015: 26) explains that there are simply five characteristics of the psychosocial behaviour of industrial communities, namely: (1) Belief in oneself; (2) Think rationally; (3) Open to innovation; (4) Utilization of technology; (5) Consumer behaviour. Observing and analyzing the social behaviour of the employees of PT Indorama Synthetic Tbk in Purwakarta, it can be concluded that the employees of PT Indorama Synthetic Tbk are included in the category and representation of industrial communities in Purwakarta. The definitions and characteristics of the industrial society that have been described will be found inherently in the social lives of the employees of PT Indorama Synthetic Tbk in Purwakarta.

The employees of PT Indorama Synthetic Tbk as an industrial society certainly have unique characteristics and are different from other community groups. Differences in these characteristics will be observed in aspects of 
sociology, psychology, and anthropology. Based on the results of more in-depth studies and observations, in addition to the social, behavioural, and cultural aspects of industrial society, religious aspects are essential and strategic entities to be studied and analyzed more intensely. The relationship between religion and industrial society is exciting. It needs to be studied in a more in-depth and comprehensive study, including also with the phenomena, reality, and dynamics of Islamic da'wah in industrial society. The study of Islamic da'wah in the industrial community is a study that must be done because the results of this study are expected to be able to describe the religious behaviour and da'wah activities of the industrial community. It is useful for practitioners in carrying out da'wah activities in industrial societies that tend to be individual, heterogeneous, secular, plural and multicultural.

The assumptions and issues that develop to date say that industrial society, as part of modern society tends not to pay attention to matters relating to religion. This phenomenon of "religion in modern industrial society" has previously been widely studied and researched by Roland Robertson (1980), Thomas Luckman (1967), and B.R. Wilson (1966). This study of Islamic da'wah in industrial societies attempts to complete and fill the void of religious studies in industrial societies that are more focused on the phenomena and dynamics of Islamic da'wah in an industrial society that comes from employees of a factory.

Observing the issue of the complexity and heterogeneity of the social and religious life of industrial communities in Purwakarta, this study will try to examine more deeply the activities and realities of Islamic da'wah at PT Indorama Synthetics Tbk Purwakarta. The study is significant and strategic to do because theoretically, the results of this study are expected to contribute to the study of da'wah, especially in the context of da'wah in the industrial era today. In contrast, practically, the results of this study are expected to be a frame of reference in carrying out the practice of da'wah in industrial communities and certain groups of people with similar characteristics.

Based on this background, this study will be directed to two main focus areas, namely: First, the religious behaviour of PT Indorama Synthetics Tbk Purwakarta employees; Second, the da'wah activities of PT Indorama Synthetics Tbk Purwakarta employees. This da'wah activity specifically will be focused on a variety of Islamic da'wah activities held and participated by PT Indorama Synthetics Tbk Purwakarta employees. The results of this study are expected to contribute and provide recommendations on two main points: First, theoretically, this study is useful in the interests of developing more contemporary and contextual da'wah science. Secondly, this study is practically useful for practitioners and da'wah activists in carrying out Islamic da'wah activities in particular community groups.

Based on the results of previous research, the study of Islamic da'wah in 
the industrial community is not the first time. Previously there have been several results of previous studies that examined and observed the phenomena of Islamic da'wah in industrial societies. Based on the results of the literature review of previous research, it is found that several study results regarding Islamic da'wah in the industrial societies include Widodo \& Fathurohman (2019: 49-65), Riady (2018: 17-30), Kharisma (2018), Kusnawan (2016: 355-374), Al-Anshori (2015), and Suhartono (2014).

The results of the earlier research generally showed the dynamics of Islamic da'wah that developed following changes in society, especially in industrial societies. From the analyzation, there are two essential things obtained in this study, namely: First, the aspect of relevance (equality). The five previous studies used as literature reviews in this study have relevance in terms of the main study and the object of research. In terms of studies, the relevant previous research has similarities with this study, which is about the phenomenon of diversity and the dynamics of Islamic da'wah. At the same time, the similarities in terms of the object of study are urban, modern, and industrial society.

Second, the aspect of relevance (difference). The five previous research results that became the literature review in this study have a significant difference, especially in terms of novelty discussion and study. The study has a distinctive difference with previous research that has been done a lot, namely in a more contemporary and contextual discussion about the phenomena, dynamics, and reality of Islamic da'wah in the Indonesian community. This study examines contemporary religious behaviour and activities of Islamic da'wah in the social environment of the industrial community. In contrast, contextually this study observes the employees of PT Indorama Synthetics Tbk Purwakarta as a representation and category of industrial society that is increasingly developing in the current era of technology and industry.

Observing the results of previous studies discussing Islamic da'wah in industrial societies, most of them only study and analyze the phenomenon of Islamic da'wah theoretically and generally. Then from the object of study, namely the industrial community is still too broad, have not explicitly observed a truly actual industrial society and contextual. Based on some of the results of previous studies, this study comes with aspects of novelty that lie in studies and objects of more contemporary and contextual studies. The results of this study are expected to fill in the blanks or complete studies with the theme of Islamic da'wah in the industrial community that significantly discusses religious behaviour and da'wah activities in the industrial community. Moreover, accurately observe the employees of PT Indorama Synthetics Tbk as objects of study in the context of industrial society.

Some of the results of previous research described, function as positioning (mapping the position) of this study with previous research that has a similar subject matter. This study focuses on the religious behaviour and da'wah 
activities of PT Indorama Synthetics Tbk employees as an industrial society. The study is significant and needs to be done because the results of this study are expected to be a guide for academics and practitioners in carrying out da'wah activities in the industrial community that is increasingly developing in this modern era. Besides, the results of this study are expected to have contributive value for the development of Islamic da'wah that is more contemporary and contextual in keeping with the development of the times today.

\section{RESULTS AND DISCUSSIONS}

\section{The Religious Behavior of P'T Indorama Synthetics Tbk}

The phenomenon and reality of Islamic da'wah in industrial society is a unique and exciting study. It will try to reveal the lives and religious experiences of employees of PT Indorama Synthetics Tbk Purwakarta, which is an industrial society that has essential characteristics that lead to mechanistic things, programmed, and formality. The characteristics inherent in the employees of PT Indorama Synthetics Tbk are constructed because of the work culture in the industrial world that demands to work quickly, follow the mechanical flow, and carry out programs that have been designed. It is the work culture environment that shapes the characteristics of these employees into a group that tends to be mechanistic, normative, and formalistic.

The study of the phenomena, dynamics, and reality of religious behaviour and the activities of Islamic da'wah at PT Indorama Synthetics Tbk is indeed grounded in the theoretical and practical study of da'wah science. In practice, this study specifically refers to two main theories, namely: First, the theory of religious typology. This theory is used as an analytical tool to observe and study the religious behaviour of industrial societies. Second, the theory of the da'wah strategy. This theory is used as an analytical tool in dissecting and reviewing the reality of the da'wah activities of the industrial community. This study uses a case study method. The case study method is a research method that investigates, traces and observes a program, event, activity, process, or group of individuals (Creswell, 2013: 20). In the context of this study, the case study method is directed at searching, digging more profound, and examining various da'wah activities carried out by PT Indorama Synthetics Tbk Purwakarta employees as representatives of today's industrial society.

This study was conducted using the naturalistic paradigm. The naturalistic paradigm is often also called the natural paradigm. Natural paradigm (naturalistic) in this study is sourced from the view of phenomenology (Nurhadi, 2015: 8). It seeks to understand human behaviour in terms of the framework of thinking and acting human perspective itself (Moleong, 2014: 31). The naturalistic paradigm in this study is used operationally. To observe, examine, and understand the religious behaviour in the natural activities of industrial 
society based on the perspective and framework of personal and communal experiences of PT Indorama Synthetics Tbk Purwakarta employees.

This naturalistic paradigm study uses a qualitative approach. Practically, a qualitative approach and a study emphasize the importance of understanding behaviour according to the mindset and action of the subject of study. Therefore the naturalistic paradigm is closely related to the qualitative approach (Nurhadi, 2015: 10; Mulyana, 2013; Rakhmat, 2012 ). This qualitative approach produces descriptive data about spoken or written words and observed behaviours of the subjects studied (Bogdan \& Yalor, 1992). In the context of this study, a qualitative approach was applied to be able to understand the mindset and variety of actions of the employees of PT Indorama Synthetics Tbk as an industrial society. Observations with this qualitative approach produce descriptive data that contains information and information from several speakers who come from PT Indorama Synthetics Tbk employees as research subjects.

The case study method requires steps and data collection techniques that must be relevant to the object and subject of the study. According to Robert K. Yin (2013: 103), the data collection techniques in this study use two techniques, namely: observation and interview. The data collection technique is operationally used to explore and trace the data needed to analyze Islamic da'wah activities among PT Indorama Synthetics Tbk Purwakarta employees as an industrial society.

The observation technique was carried out by observing nine observation objects which included: (1) Space (PT Indorama Synthetics Tbk area); (2) Actor (the employee of PT Indorama Synthetics Tbk); (3) Activity (employee activities of PT Indorama Synthetics Tbk); (4) Object (artefacts of PT Indorama Synthetics Tbk); (5) Act (actions of employees of PT Indorama Synthetics Tbk); (6) Event (series of da'wah activities at PT Indorama Synthetics Tbk); (7) Time (time of da'wah activities at PT Indorama Synthetics Tbk); (8) Goal (the purpose of da'wah activities at PT Indorama Synthetics Tbk); and (9) Feelling (emotions and expressions of employees of PT Indorama Synthetics Tbk). In practice, data collection techniques using interview techniques use in-depth interviews, which are obtained information through dialogue from several employees of PT Indorama Synthetics Tbk Purwakarta who are the primary informants.

This study uses Huberman \& Miles' model data analysis techniques. This model requires three stages in analyzing data, namely data reduction, data display, and conclusion drawing (Emzir, 2012: 129). At this stage, this study begins by collecting and digging out the necessary data, then the data collected has been reduced (data reduction) into two classifications, namely data on religious behaviour and da'wah activities of PT Industri Synthetics Tbk Purwakarta employees. After the data has been reduced, then the data is presented (data display) in the compartment. The final stage is to conclude (conclusion drawing) the study results from the data analysis presented in the 
second stage.

Analyzing from the perspective of religious behaviour, of course, the characteristics of industrial society also influence religious behaviour (Bauto, 2014; Hamali, 2015; Thaha \& Ilyas, 2016) of these employees. Therefore, this study will try to review and discuss more deeply related to da'wah activities among PT Indorama Synthetics Tbk Purwakarta employees. The discussion indeed cannot be separated from the religious behaviour of the employees themselves, because integrally the activities of Islamic da'wah (religious activities) will be strongly influenced by religious behaviour patterns, both personally and communally (Nuwairah, 2014; Sholikhin, 2015; Hayati, 2017; Qorib, 2018). Therefore, the starting point of this study begins with a more in-depth review and discussion related to the religious behaviour of the industrial community, which is practised by the employees of PT Indorama Synthetics Tbk Purwakarta.

Based on observations at the locus of the study and strengthened with information from several informants, it is known that the employees of PT Indorama Synthetics Tbk as an industrial community fully recognize and realize that "religion" is essential in human life (Arif, 2015; Haryanto, 2016; Mulyadi, 2016). Some interviewees even revealed that religion is the essential thing in human life, especially for Indonesian people who are attached to religious identity. Therefore, based on some statements from PT Indorama Synthetics Tbk employees who are predominantly Muslim, they believe that Islam is their way of life. Besides, they also believe that there will be a life in the afterlife in the world. Therefore this aspect of religion becomes very basic for human life (Latif, 2016; Trimurni, 2017; Mahfud, 2018; Abdillah, 2019). Then in terms of other thoughts, they also understand and believe in the concepts of "sin" and "reward". Therefore, primarily and substantially, the employees of PT Indorama Synthetics Tbk Purwkarta believe that religion is the most fundamental thing for human life.

This belief in religion is practised by the employees of PT Indorama Synthetics Tbk by practising daily worship and other religious orders. Based on field observations, the employees of PT Indorama Synthetics Tbk always perform the five daily prayers and other ritual worship. Such as reading the Koran, following the recitation, conducting fasting during Ramadan, performing zakat fitrah, performing qurban on Eid al-Adha, as well as other rituals and formal worship. It can be said that from the aspect of religious practice, the industrial community in a ritual and formal manner is still carrying out what is ordered in religion. Furthermore, in terms of religious behavior oriented to social values, the employees of PT Indorama Synthehtics Tbk as a representative of this industrial society, also participated in worship and religious celebrations that were momentum, or in the expression of popular Indonesian people with the term PHBI (Celebration of Islamic Holidays). 
In the context of religious behaviour oriented toward social values, the employees of PT Indorama Synthetics Tbk also participate and contribute to PHBI, such as the Commemoration of the Prophet Muhammad's Birthday, Commemoration of Isra Mikraj, or other similar activities. Then regularly, these employees often attend taklim assemblies held by the mosque around their residence, or even Islamic studies and religious formation conducted formally by PT Indorama Synthetics Tbk. Furthermore, personally, there are also employees of PT Indorama Synthetics Tbk who are board members of DKM, ZIS managers, members of Islamic mass organizations, and members of religiousrelated institutions.

Another finding revealed through interviews with several employees of PT Indorama Synthetic Tbk is the explanation that those who applied religious practices are to fulfil the obligations of religious orders. They substantively understand and realize that as Muslims inevitably have to carry out and practice the primary worship required for a Muslim. Therefore, based on the acknowledgement of several informants that what they did was to carry out religious orders, the rest they did not understand deeply the meaning and wisdom contained in each of those worships. According to the confession of a resource person, who is a long time employee of PT Indorama Synthetics Tbk, it is explained that these employees are accustomed to working patterns that are procedural, programmed, and mechanically controlled. Thus, that work patterns carried in social life patterns and behaviour patterns diversity. Still, according to the informant, it was said that it was natural that PT Indorama Synthetics Tbk employees would participate and contribute to religious activities oriented to social values. Then, they still took the time to perform congregational prayers at the mosque in their neighbourhood. Even if there were employees who did not come to work at the factory, they still had time to attend the study conducted by the Mosque or Taklim Council around their residence. The work environment that always demands to follow things that are set and programmed, also indirectly affects the social context in their lives. Therefore, the employees of PT Indorama Synthetics Tbk can easily participate in social and religious activities that have been programmed by the management of the activities in their neighbourhood.

Analyzing the information obtained from several employees of PT Indorama Synthetics Tbk who were the resource persons in this study, it can be seen that in reality, the religious behaviour of the industrial community tends to be normative and formal. It can be identified on two things, namely: First, religious thought; Second, the religious practice. These two things become indicators to be able to know the diversity of behaviour patterns of PT Indorama Synthetics employees as an industrial society. From the aspect of religious thought, the employees of PT Indorama Synthetics Tbk have normative thinking. Because they place religious entities as the basis and 
guidelines for religious human life, even though at the level of knowledge about the nature and essence of religion, they do not understand more deeply. Thus, it can be said that what they think about religion is only limited to normative and dogmatic knowledge. Industrial societies view religion as a sacred and final entity, and therefore they are not entitled to intervene in matters relating to religion. Therefore they sometimes accept the "whole" contained in religious teachings, including all concepts and religious dogma (Muhammad, 2013; Mibtadin, 2016; Arroisi, 2017). In the implication, they always believe in everything contained in the teachings of religion, without any objection, let alone rejection. Religious thought like this can be called normative religious thought.

From the aspect of religious practice, employees of PT Indorama Synthetics Tbk as an industrial society include conducting formal religious practices. Religious practices carried out by PT Indorama Synthetics Tbk employees are merely formal ritual activities. Some religious practices, such as congregational prayers, fasting, almsgiving, charity, qurban, attending recitals, or other ritual worship, are only to carry out what is required by religion. Besides, religious practices with such a pattern, sociologically also become a kind of reinforcement of religious identity (Rozi, 2013; Mujahididn, 2015; Hakim, 2016; Wirawan \& Kurniawan, 2017) for those who participate and contribute in religious activities. Therefore, in reality, what is practised by industrial society in the religious context is only oriented towards things that are ritual and formal, without something attached or imprinted on each individual. It can be said that religious behaviour patterns tend to be empty without meaning, because what they do is only at the level of exoteric not yet possess the esoteric level (Syafaq, 2012; Syamsuri, 2013; Ikbal, 2015; Anieg, 2016).

Observing the diversity of PT Indorama Synthetics Tbk's behaviour as described above, it can be concluded that the religious behaviour of industrial society is included in the diversity behaviour with formalism. It is essential to study more in-depth that merely the religious behaviour of formalism is religious behaviour that tends to be ritual-formal, and only fulfils the obligations of religious orders. Concerning the type of religious behaviour, Imam Suprayogo \& Tobroni (2003: 42) classifies a person's religious behaviour into five types, namely: (1) Pietism, religious behaviour that aims to achieve peace in life; (2) Ritualism, religious behaviour that emphasizes the rules of worship rather than the purpose of worship itself; (3) Formalism, religious behaviour which views that worship is solely due to the obligation of religious orders; (4) Aestheticism; religious behaviour that prioritizes the implementation of worship from the aspect of the beauty of its facilities and processes so that the substance of worship may not be touched; (5) Ecipism, religious behaviour that makes worship a way for humans to escape from burdens and perhaps the responsibilities they carry. 
Concerning this type of religious behaviour, Gordon W. Allport (1967) also divides two kinds of religious methods, namely extrinsic and intrinsic. The first way of religion is to see religion as something to be used, and not for life, something to use but not to live. In an extrinsic way, religion is used to support other motives outside of religion, such as the need for status, security, or selfesteem. According to Rachmat (1993: 26), extrinsic religious people carry out external forms of religion, such as fasting, prayer, pilgrimage, and others as, but not the result of worship does not permeate in him. The second way of religion is to view religion as an absolute commitment and driving integrating motive, which governs one's entire life. Religion is accepted as a unifying factor. Based on the first way, according to Rachmat (1993: 26) the natural way of religion can be pierced into the adherents.

Borrowing the two ways of religion from Allport, it can be said that the religious behaviour of the employees of PT Indorama Synthetics Tbk Purwkarta enters the extrinsic religious way. It has been explained before, that in reality every thought and religious practice of PT Indorama employees is only in the outer layer of religious awareness, values, meanings, philosophies, and the wisdom of worship. It does not possess the employees of PT Indorama Synthetics Tbk. It is even based on the results of interviews with informants, some religious practice obligations aimed at strengthening the identity and social status of a religious person. Further, according to Allport, religion is referred to as something to use but not to live, religion as a personal motive.

According to Zalikhoh (2015) on her quantitative studies about the religious behaviour of industrial communities in Dayeuh Kolot, Bandung. It is found that she made a percentage with three categories, namely religious beliefs, religious understanding, and religious experience. From the percentage of the three categories, the highest number that reached 97 per cent was in the aspect of religious belief, while the lowest number which only reached 50 per cent was in the aspect of the understanding. From the results of the study, it can be seen that in terms of religious understanding, industrial communities in Dayeuh Kolot Bandung are among the lowest numbers. It is the same as the reality of the industrial community in Purwakarta, which shows that in terms of religious thought, it still tends to be normative.

The results of another study that discusses the religious behaviour of industrial societies was revealed by Kharisma (2018). In his study, Kharisma examined the effect of industrialization on the diversity of the people in Ngoro, Mojokerto. The results of his study indicate that the level of religious knowledge and understanding of the people in Ngoro, Mojokerto is classified as low. Observing the results of the study has relevance to the studies conducted. In substance, the relevance is in the low and normative aspects of religious thought. However, some things are criticized from the studies done by Zalikhoh and Kharisma, namely the research subject is still too broad and not yet specific. In 
contrast to this study, the subject of the study, which is industrial society, is distinct and explicitly mentioned, namely the employees of PT Indorama Synthetics Tbk, located in Purwakarta.

To conclude, it can be said that the religious behaviour of industrial people belongs to the type of formalism, namely the implementation of worship is only used as a ritual and formal activity. It is not rooted firmly on the esoteric side of every employee of PT Indorama Synthetics Tbk. Next, some findings will be discussed regarding the da'wah activities that exist in the social environment of PT Indorama Synthetics employees as industrial communities in Purwakarta.

\section{Da'wah Activities of PT Indorama Synthetics Tbk's Employees}

Specifically, this discussion contains a description of the findings of the study relating to the reality and dynamics of Islamic Da'wah activities contained in the lives of the employees of PT Indorama Synthetics Tbk as a representation of the industrial society in Purwakarta. The findings and discussion presented in this section are obtained from observations and observations of the da'wah activities of PT Indorama Synthetics Tbk Purwakarta employees. The results of observing the da'wah activities are classified into a description of the variety and forms of Islamic da'wah activities in the industrial society.

Based on observations in the locus of the study, it was found several types and forms of da'wah activities that were focused on Islamic da'wah activities organized by PT Indorama Synthetic Tbk Purwakarta. Specifically, there are four religious activities included in the Islamic da'wah activities organized by PT Indorama Synthetics for its employees. The activities are (1) Ba'da Friday Recitation Activity; (3) Monthly Development of Employees; Commemoration of Islamic Holidays; (4) Distribution of ZIS and Meat of qurban. In more detail about the description of the four activities, explained below:

First is the recitation activities on Friday. The activity is a da'wah activity that is routinely carried out once a week, which is every Friday. After completing the Friday prayers in congregation, the DKM of PT Indorama Synthetics Tbk Factory Mosque held an Islamic study containing lectures or religious discussions. The theme of the discussion, usually around the discussion of practical Islamic laws in daily life and other Islamic sciences. The activity usually lasts for approximately one hour. However, in reality, these activities tend to be "quiet enthusiasts", there are only a few employees who follow the study. Most of the employees chose to take a midday rest after completing Friday prayers in congregation at the Factory Mosque. Only a handful of employees survived after the Friday prayers to attend the routine review. This study is more informal than formal (Zaini, 2018; Yushedi, et.all, 2019), in this sense outside of the obligations that must be followed by employees. Because of this, what causes this activity is only followed as a small employee. Though this activity is beneficial to increase 
knowledge of Islamic sciences that are expected to seep deeper into each employee.

Second, the monthly development of employees. This activity becomes upgrading activities for employees. This activity is carried out every two months. The contents of this activity are almost the same as the Friday Ba'aan recitation activities as described in the first point. However, for this monthly development activity, the event is more formal and ceremonial (Yeemayor, 2015). Because this is a program from the factory, there are many participants, even almost all employees. This activity contains a briefing accompanied by a study that specifically discusses the work ethic in terms of a religious perspective. The essential purpose of this activity is to regain the enthusiasm of working for employees (Tobroni, 2015; Aliyah, 2018; Harahap, 2018; Sani, 2019), besides through this activity also instilled an understanding that work is part of worship. According to its purpose, this activity is very beneficial for improving employee work ethics. However, unfortunately, this activity does not yet have a significant impact on employees because it might be a bored and normative activity. Therefore employees who take part in this activity are only to fulfil program obligations organized by the factory, not yet fully aware of the importance of religious guidance to improve ethos and productivity at work.

Third, the commemoration of the Islamic holiday. In Indonesian society, religious activities with a relatively large scale of events are called PHBI (Commemoration of Islamic Holidays) (Nurdin, 2016; Alfiyah, 2016; Kurdin, 2018; Muslim, et.all, 2018). PHBI includes the celebration of the Prophet's Birthday, Isra Mikraj, Hijri New Year, Eid al-Fitr, and Eid al-Adha. Based on this, PT Indorama Synthetics Tbk also routinely holds PHBI activities through annual events. For example, during the commemoration of the Prophet's Birthday and Israa Mikraj, the PT Indorama Synthetics Tbk factory routinely holds a grand tablig intended for all factory leaders and employees. The grand tablig usually contains public lectures delivered by preachers who are intentionally invited by PT Indorama Synthetics Tbk's PHBI event committee. The event was held in the factory hall and lasted about two hours plus other events. Then in addition to the PHBI Maulid of the Prophet and Israj Mikraj, PT Indorama Synthetics Tbk also often held prayers in the congregation of Eid al-Fitr and Eid al-Adha in the factory field with the employees and the surrounding community. It is a little challenging to be able to measure the impact of this PHBI activity for employees, because in general in the culture of Indonesian society this PHBI activity becomes a year event that is held ceremonially at all levels of society. Even further than that, the PHBI's activities in the culture of Indonesian society became a distinctive identity inherent in the Indonesian nation. Back to the context of the da'wah activities carried out by PT Indorama Synthetics Tbk, pragmatically this PHBI activity further complements the activities of Islamic da'wah in the industrial society of PT Indorama Synthetics Tbk Purwakarta 
employees.

Fourth, the distribution of ZIS and qurban meat. These activities include PHBI Eid al-Fitr and Eid al-Adha. As shared in the Indonesian community that every moment of Eid al-Fitr has distributed assistance in the form of Zakat Infaq and Shodaqoh (ZIS) for the recipients who are entitled, so at Eid al-Adha also distributed qurban meat. Every Eid Al-Fitr and Eid al-Adha, PT Indorama Synthetics Tbk assists in the form of ZIS to the recipients that have been previously recorded by the committee, while for Eid al-Adha the factory often slaughtered qurban animals ranging from goats to cows. The qurban meat is first distributed to the rightful recipient. Then the rest is usually distributed to the employees. In practice, this zakat and qurban is ritual worship that includes Eid al-Fitr and Eid al-Adha which every Muslim must carry out (except for the qurban, there are certain conditions). However, what is relevant and interesting to review, PT Indorama Synthetics Tbk always routinely distributes ZIS and qurban meat every year. Just like the PHBI activities, specifically looking at the impact of this da'wah activity for employees, but with this activity employees who intend to pay zakat and do qurban can be facilitated by the factory, and this becomes da'wah through empowering all parties (Nasution, et.all, 2018; Dauly, 2018; Aminudin, 2019).

Analyzing all the reality and dynamics of da'wah activities in PT Indorama Synthetics Tbk Purwakarta, it can be said that Islamic da'wah activities in this industrial society are more temporal, monumental, and ceremonial. Such da'wah activities tend to have less influence and impact on the mad'u, or in this context the employees of PT Indorama Synthetics Tbk Purwakarta. There is a need for more intense and routine da'wah activities, not just at certain times. The more intense da'wah activities are expected to be able to have a more powerful influence on the employees. Then, on the other hand, it is possible that the da'wah activities organized by PT Indorama Synthetics Tbk Purwakarta are already too mainstream and even tend to be monotonous. Therefore, seeing these conditions, it seems necessary to carry out a new format in carrying out da'wah activities.

The format of Islamic da'wah activities carried out in industrial societies must naturally adjust to the context and needs of industrial societies, because as has been revealed previously that industrial societies have their characteristics. Based on this reality, the ideal of da'wah activities is more under the characteristics of industrial society. Adjustment of da'wah activities for the industrial community can be made through three aspects: First, from the aspect of da'wah. In delivering da'wah to the industrial community, it is expected to choose the right preacher, because this is the first key to the success of Da'wah. For example, try to choose a preacher who understands, or at least knows, the dynamics of the industrial world, the conditions of production and factory 
consumption, to the problems that exist in the urban environment. Second, from the material aspect. Moreover, it must also be adjusted da'wah material delivered. The material presented, ideally, should have relevance to matters of industrial, work, or broadly deliver da'wah material about the perspective of Islamic teachings on the work ethic. Theoretically, the relevance of "religion and work ethic" has been widely studied, one of which is by Max Weber (1930). What was written by Weber, can be applied in the context of da'wah in this industrial society. For example, delivering material about the merits or virtues of work, work is part of worship, work is the noblest jihad, and so forth. Third, from the aspect of the method. Several times it has been revealed if one of the characteristics of industrial society is programmed and mechanistic. Therefore, based on these characteristics, ideally, methods of da'wah that are straight to the point, practical and applicable to use.

The selection of da'i, materials and methods of da'wah that are appropriate to the characteristics of the industrial society will significantly assist in the realization of Islamic da'wah activities that are effective and on target. Pragmatically, according to Asep Muhyidin (2014: 22), if you want da'wah activities to be conveyed and well-received, then at least three of these rules must be fulfilled, namely: First, delivering the message of da'wah by the intellectual capacity of the object of da'wah; Second, delivering the message of da'wah following the language of the people who are the object of da'wah; Third, convey the message of da'wah by social, economic, and cultural conditions that are the object of da'wah. Furthermore, Muhyidin (2014: 151) revealed that several methods could be used in carrying out da'wah in industrial societies that have characteristics almost identical to those of urban society, namely: (1) Using a da'wah approach that is structural and cultural in a dynamic, rational and democratic manner; (2) Using informative spoken and written language; (3) Using a practical (charity) approach that is praxis and pragmatic; (4) Using a bottom of structure approach; (5) Using the existing institution in urban areas as a method as well as da'wah media.

Some studies on Islamic da'wah studies in industrial societies have the same relevance as the results of this study, such as studies conducted by Widodo \& Fathurohman (2019). The study discusses the phenomenon of Islamic da'wah in the industrial revolution era 4.0. The study results conclude that there must be a da'wah strategy that is following developments in the era of the industrial revolution 4.0. However, there is a thing that needs to be criticized from the results of the study. It does not mention the strategy as to what to do in carrying out da'wah in the era of the industrial revolution 4.0. In contrast to the results of the Widodo \& Fathurohman study, the results of this study try to provide alternative strategies in carrying out da'wah activities with audiences of the industrial community, namely in three ways: the selection of the right preachers, the selection of appropriate materials, and the selection of useful methods. Thus, 
the results of this study are expected to be able to contribute to the development of Islamic da'wah in the era of the industrial revolution and the era of disruption, such as the current hegemony.

Based on the findings of the da'wah activities of PT Indorama Synthetics Tbk employees, it can be concluded that the Islamic da'wah activities carried out so far are still likely to be temporal, monumental, and ceremonial. Furthermore, to simplify the understanding of the findings and results of this study, it is schematically illustrated in the scheme as below:

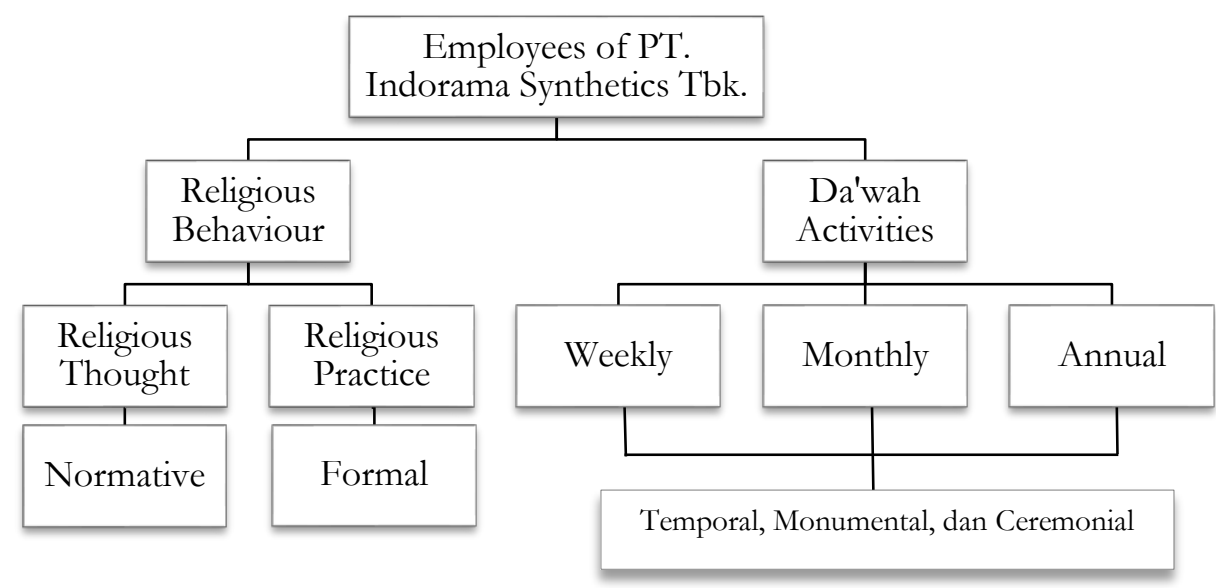

\section{CONCLUSION}

Based on various study findings that have been presented and analyzed in the discussion section, it can be concluded that the activities of Islamic da'wah in this industrial society need further efforts. Thus Islamic da'wah activities achieve goals that are appropriate and well-targeted for industrial societies which have their characteristics. In summary, there are two essential points found in this study, namely: First, the religious behaviour of industrial societies still tends to be normative and formalistic; Second, the activities of da'wah in industrial society are still temporal, monumental, and ceremonial.

Referring to the findings and conclusions of the study, at least two things become the significance and recommendations of this study, namely: First, the need for efforts to internalize religious values towards industrial society. This internalization effort is expected to shape the spirit of professionalism based on religion. Second, there is a need for intensification of da'wah activities for the industrial community. This intensification effort aims to further arouse the spirit of professionalism in work based on religious values.

The results of the study are expected to contribute to the development of Da'wah science and practice of Da'wah activities in the industrial community, or 
similar community groups that are undergoing modernization and industrialization. This study generates alternative da'wah strategies that are more contemporary and contextual with the dynamics and reality of industrial society. The strategy includes the following three things, namely: (1) Selection of the right preachers; (2) Selection of suitable material; and (3) Selection of useful methods. Hopefully, the da'wah strategy produced through this study can be applied and developed practically and pragmatically.

\section{REFERENCES}

Abdillah. (2019). Eskatologi: Kematian dan Menjadian Manusia dalam Jaqfi: Jurnal Aqidah dan Filsafat Islam, 1 (1), 121-134.

Al-Anshori, MZ. (2015). Implementasi Dakwah di PT Inco Surowako. Tesis, Program Studi Dakwah dan Komunikasi, UIN Alauddin Makasar.

Alfiyah, K. (2016). Kegiatan Dakwah dalam Upaya Peningkatan Akhlakul Karimah dalam Masyarakat, Al-Irsyad, 3 (1), 1-24.

Aliyah, S. (2018). Bimbingan Keagamaan untuk Menginkatkan Etos Kerja dalam Al-Irsyad, 2 (2), 58-79.

Allport, GW. (1967). The Individual and His Religion. US: Oxford University.

Aminudin, MZ. (2019). Pengelolaan ZIS dalam Upaya Meningkatkan Masyarkat dan Penanggulan Kemiskinan dalam Ziswaf: Jurnal Zakat dan Wakaf, 6 (1), 80-100.

Anieg, M. (2016). Merasakan Tasawuf dalam Wahana, 3 (2), 19-36.

Arif, S. (2015). Manusia dan Agama dalam Islamuna, 2 (2), 149-166.

Arroisi, J. (2017). Sakral dan Profan dalssam Perkembangan Ideologi Politik Agama dalam Tsaqafah: Jurnal Peradaban Islam, 71-92.

Bauto, LM. (2014). Perspektif Agama dan Kebudayaan dalam Kehidupan Masyarakat Indonesia (Stuatu Tinjauan Sosiologi Agama) dalam JPIS: Jurnal Pendidikan Ilmus Soisla, 23 (2), 11-25.

Bogdan, RC \& Taylor, SJ. (1992). Inroduction to Qualitative Research Methode: A Phenomenological Approach in Social Sciences. London: Sage Publishing.

Creswell, JW. (2013). Research Design: Qualitative, Quantitative, and Mixed Methods Approaches. One Thousand Oaks: Sage Publishing.

Dauly, H. (2018). Zakat sebagai Pesan Dakwah: Antara Pengelolaan dan Perubahan Manusia dalam Tasamuh: Jurnal Studi Islam, 10 (1), 93-123.

Emzir. (2012). Metode Penelitian Kualitatif: Analsisi Data. Jakarta: Rajawali Pers.

Hakim, RA. (2016). Agama, Identitas, dan Kewarganeagaraan dalam dalam In Right: Jurnal Agama dan Hak. Azazi Manusia, 5 (2), 256-297.

Hamali, S. (2015). Sikap Keagamaan dan Pola Tingkah Laku Masyarakat Madani dalam Al-Adyan, 6 (2), 77-100. 
Harahap, AH. (2018). Efektifitas Bimbingan Rohani dalam Meningkatkan Etos Kerja dalam Hidayab: Komunikasi Penyiaran Islam, 2 (1), 67-85.

Haryanto, HC. (2016). What Are The Benefits of Religion? (Study on Islamic Religious People in Jakarta) dalam Insight, 13 (1), 19-31.

Hayati, U. (2017). Nilai-Nilai Dakwah; Aktifitas Ibadah dan Perilaku Sosial dalam Inject: Interdisciplinary Journal of Communication, 2 (2), 175-192.

Ikbal, M. (2015). Memahami Agama dengan Pendekatan Esoterik dalam Kalam: Jurnal Studi Agama dan Pemikiran Islam, 9 (1), 1-16.

Kharisma, AC. (2018). Pengaruh Industrialisasi terhadap Religiusitas dan Spiritualitas Masyarakat dalam Filsafat Agama, 2 (4), 10-25.

Kurdi, AJ. (2018). Dakwah Berbasis Kebudayaan sebagai Upaya Membangaun Masyarakat Madani, Jurnal Studi Ilmu-Ilmu al-Qur'an dan Hadits, 19 (1), 20-42.

Kusnawan, A. (2016). Dakwah pada Masyarakat Teknologi dalam Ilmu Dakwah: Academic Journal for Homiletic Studies, 10 (1), 355-374.

Latif, U. (2016). Konsep Mati dan Hidup dalam Islam (Pemahaman Berdasarkan Konsep Eskatologis) dalam Al-Bayan, 22 (34), 27-38.

Luckman, T. (1967). The Invisible Religion: The Problem of Religion in Modern Society. London: MacMillan.

Mahfud. (2018). Tuhan dalam Kepercayaan Manusia Modern (Mengungkap Relasi Primordial Antara Tuhan dan Manusia) dalam Cendekia: Jurnal Studi Keislaman, 1 (2), 97-112.

Mibtadin. (2016). Kritik Teori Masyarkaat Sakral dan Masyarakat Profan dalam Smart: Studi Masyarakat, Religi, dan Tradisi, 2 (1), 1-13.

Moleong, LJ. (2014). Metode Penelitian Kualitatif. Bandung: Remaja Rosdakarya.

Muhammad, N. (2013). Memahami Konsep Sakral dan Profan dalam AgamaAgama dalam Substansi, 15 (2), 268-279.

Muhyidin, A. (2014). Metode Pengembangan Dakwah. Bandung: Pustaka Setia.

Mujahidin, A. (2015). Umat Beragama seabgai Masyarakat Beradab: Identitas Agama VS Kebangsaan dalam Kalam: Jurnal Studi Agama dan Pemikiran Islam, 9 (1), 17-30.

Mulyadi. (2016). Agama dan Pengaruhnya dalam Kehidupan dalam Al-Awlad: Jurnal Tarbiyah, 6 (2), 556-564.

Mulyana, D. (2013). Metode Penelitian Kualitaitf: Paradigma Baru Ilmu Komunikasi dan Ilmu Lainnya. Bandung: Remaja Rosdakarya.

Muslim, NM, et.all. (2018). Tantangan Dakwah pada Masayrakat Multikultural dalam Wardah, 19 (2), 122-134.

Nasution, AH. et.all. (2018). Kajian Strategi ZIS dalam Pemberdayaan Umat dalam Jurnal Ekonomi Bisnis Syariah, 1 (1), 22-37.

Nurdin, A. (2016). Integrasi Agama dan Budaya: Kajian tentang Tradisi Maulid dalam Masyarakat dalam el-Harakah, 18 (1), 45-62. 
Nurhadi, ZN. (2015). Teori-Teori Komunikasi: Teori Komunikasi dalam Perspektif Penelitian Kualiatatif. Bogor: Ghalia Indonesia.

Nuwairah, N. (2014). Dakwah di Tengah Keragamana Masyarakat: Hakikat dan Stretegi dalam Alhadarah: Jurnal Ilmu Dakwah, 13 (25), 15-25.

Qorib, M. (2018). Dakwah di Tengah Pluralitas Masyrakat dalam Intiqad: Jurnal Agama dan Pendidikean Islam, 2 (5), 315-333.

Rakhmat, J. (1993). Islam Alternatif: Ceramah-Ceramah di Kampus. Bandung: Mizan. Rakhmat, J. (2012). Metode Penelitian Komunikasi: Dilengkapi Contoh Analisis Statistik. Bandung: Remaja Rosdakarya.

Riady, AS. (2018). Agama Industri Pedesaan (Studi Perilaku Keberagamaan Akibat Dampak Industri di Masyarakat Dukuh Nologaten, Caturnuggal Sleman) dalam Sosioreligius, 3 (2), 17-30.

Robertson, R. (1980). Agama: Dalam Analisa dan Interpretasi Sosiologis. Jakarta: Rajawali Pres.

Rozi, S. (2013). Konstruksi Identitas Agama dan Budaya dalam Jurnal Masyarakat Indonesia, 39 (1), 215-245.

Sani, NAM. (2019). Kontribusi Bimbingan Keagamaan dalam Meningkatkan Etos Kerja Karyawan dalam Iqro: Jurnal Ilmu Keislaman, 1 (2), 30-55.

Scott, J. (2012). Teori Sosial: Masalah-Masalah Pokok dalam Sosialologi. Yogyakarta: Pustaka Belajar.

Sholikhin, M. (2015). Berbagai Masalah Keberagamaan Masyarakat Industri dalam Perspektif Dekonstruksi Dakwah Berbasis Psikologi Sosial dalam Jurnal Komunika, 9 (1), 1-18.

Soekanto, S. (2007). Sosilogi: Suatu Pengantar. Jakarta: Raja Grafindo Persada.

Suhartono. (2014). Dakwah pada Masyarakat Industri Kecil (Studi pada Masyrakat Penggrajin Genteng di Mojokerto) dalam ad-Dakwah: Jurnal Ilmu Dakwah, 3 (2), 70-90.

Suprayogo, I \& Tobroni. (2013). Metdologi Penelitian Agama. Bandung: Remaja Rosdakarya.

Syafa, H. (2012). Relasi Pengetahun Islam Eksoteris dan Esoteris dalam Teosofi: Jurnal Tasawuf dan Pemikiran Islam, 2 (2), 33-347.

Syamsuri. (2013). Memadukan Kembali Ekstorisme dan Esoterisme dalam Islam dalam Miqot, 37 (2), 291-312.

Thaha, H \& Ilyas, M. (2016). Perilaku Beragama dan Etos Kerja Masyarakat Pesisir di Kelurahan Penggoli Kecamatan Wara Utara Kota Palopo dalam Palita: Journal of Social-Religi Research, 1 (1), 1-16.

Tobroni, S. (2015). Hubungan Intensitas Mengikuti Kegiatan Pembinaan Agama Islam dengan Etos Kerja dalam Al-Isryad, 4 (2), 112-125.

Trimurni, S. (2017). Hakekat dan Tujuan Hidup Manusia dalam Al-Irsyad al-Nafs: Jurnal Bimbingan Penyuluhan Islam, 2 (1), 57-68.

Weber, M. (1930). The Protestant Ethic and the Spirit of Capitalism. Oxford: Oxford University Press. 
Widodo, A \& Fathurohman. (2019). Dakwah Islam di Era Revolusi Industri 4.0. dalam Khabar: Komunikasi dan Penyiaran Islam, 1 (1), 49-65.

Wilson, BR. (1966). Religion in Secular Society. London: Watts.

Wirawan, AS \& Kurniawan, PS. (2017). Dinamika Strategi Penguatan Identitas Sosial Keagamaan dalam Senari, 2 (1), 213-220.

Yeemayor, MP. (2015). Strategi Pembinaan Dakwah dalam Meningkatkan Pemahaman Agama dalam Jurnal Walisongo, 4 (3), 50-73.

Yin, RK. (2013). Case Study Reasearch: Design and Methods. One Thousand Oaks: Sage Publishing.

Yushed, L. et.all. (2019). Retorika Khatib dalam Penyampaian Khutbah Jum'at dalam Al-Hikman: Jurnal Dakwah dan Komunikasi, 2 (2), 62-80.

Zaini, A. (2018). Dakwah Melalui Mimbar dan Khitabah dalam At-Tabsyir: Jurnal Komunikasi Penyiaran Islam, 1 (2), 73-90.

Zalikhoh. (2015). Pola Perilaku Keagamaan pada Masyarakat Industri. Tesis, Religious Studies, UIN Sunan Gunung Djati Bandung. 